\title{
Water, settlement and food provision in Natal Colony: The Winterton Irrigation Settlement, 1902-1904
}

\author{
Debbie Whelan*
}

\begin{abstract}
Irrigation settlements formed a vital part of infrastructural history in the former Natal Colony. Projects implemented in the late nineteenth century had a specific socio-political impetus, which shifted to a more economic strategy after the South African War. The Tugela irrigation schemes were intended as an official long term investment in food security and to diversify the potential of crop production. After 1902, the Upper Tugela Irrigation Scheme at Winterton and the Lower Tugela Irrigation Scheme at Muden were planned: both aimed at creating small, irrigated farms on which to settle "a different class of farmer", in the case of the former, medium to low income white settlers; and the latter, African farmers. Using an interface of the social and the physical, this article will discuss the Winterton Irrigation Settlement contextualised with environmental and social issues affecting food production in the 1890s. It will begin with the schematic master-plan allowing for the settlement, and discuss the identification of lands, physical construction of the water infrastructure and the surveys of the plots. It then discusses the social engineering that allowed for the allocation of lands, before commenting on the invisible role function of the furrows as ongoing infrastructure and a means of underpinning social sustainability.
\end{abstract}

Key words: Water history; Winterton; irrigation; engineering works; social sustainability; food security.

\section{Opsomming}

In die voormalige Natalkolonie het besproeiingsnedersettings 'n noodsaaklike rol in die geskiedenis van infrastruktuur gespeel. Die spesifieke sosiopolitiese impetus vir projekte in die laat-negentiende eeu het verskuif na 'n meer ekonomiese strategie na afloop van die Suid-Afrikaanse Oorlog. Die Tugela-besproeiingskemas is amptelik beoog as 'n langtermyn belegging in voedselsekerheid en om gewasproduksie te diversifiseer: die Hoër Tugela Besproeiingskema te Winterton; en die Laer Tugela

\footnotetext{
Debbie Whelan is a senior lecturer in the School of Architecture and the Built Environment at the University of Lincoln, UK. She holds qualifications in architecture, anthropology and archaeology and carries out interdisciplinary work. Her main fields of interest are vernacular architecture, cultural change and infrastructure. Her e-mail address is: dwhelan@lincoln.ac.uk. Thanks to Dr Raymund Königk (University of Lincoln) for assistance in translating the abstract.

How to cite this article: D. Whelan, "Water, settlement and food provision in Natal Colony: The Winterton Irrigation Settlement, 1902-1904", Historia, 64, 1, May 2019, pp 42-64. 
Besproeiingskeme by Muden is ná 1902 beplan. Beide het beoog om klein plase, onder besproeiing, vir 'n nuwe klas boer te vestig. Lae- tot middelinkomste wit boere by Winterton en swart boere by Muden. Hierdie artikel ontgin die koppelvlak tussen die sosiale en die fisiese ten einde die Winterton Besproeiingsnedersetting te bespreek; dit kontekstualiseer die omgewings- en sosiale kwessies wat voedselproduksie in die 1890's geraak het. Dit word ingelei deur 'n bespreking van die skematiese meestersplan vir die nedersetting wat die identifisering van grond, die fisiese bou van infrastruktuur, en die opname van erwe bepaal het. Daarna word die sosiale ontwikkeling wat die toekenning van grond beïnvloed het, bespreek. Laastens word kommentaar gelewer op die onsigbare rol van waterslote as deurlopende infrastruktuur wat sosiale volhoubaarheid onderlê.

Sleutelwoorde: Watergeskiedenis; Winterton; besproeiing; ingenieurswerke; sosiale volhoubaarheid; voedselsekerheid.

\section{Introduction}

Located on the upper reaches of the Little Tugela River in western KwaZulu-Natal, South Africa, there is a water reticulation system initiated by the colonial government in 1902, transferred and managed by the farming community whose lands it crosses, in 1926, and then absorbed into a greater Water Management Committee in 2008. Situated near the current day town of Winterton, the early twentieth-century infrastructural components of this irrigation settlement comprise a substantial concrete weir damming water which lays out to two furrows running alongside the Tugela River: these effectively served to maximise access to irrigated lands and to diversify the options for colonial-era farming in the sub-montane grasslands known as the Tall Grass Veld. ${ }^{1}$

The Winterton Irrigation Settlement was not a random and isolated initiative. Earlier projects in the Natal Colony date back to some of the first immigrant settlers. A.J. Christopher notes of the Umzimkulwana Settlement around Harding, and the Umzinto irrigation lots, in addition to the more celebrated furrows at Weenen. ${ }^{2}$ Similar initiatives were under consideration in the adjacent territories and Johann Tempelhoff considers the Vaal River in the same period, ${ }^{3}$ situating the post-South African War as central to development and weaving in the troika of mining and electrical provision as impetus for the extension of the Vaal system. Lance van Sittert describes the "supernatural" mechanisms for sourcing water in the Cape. ${ }^{4}$ Wessel

1. E. Thorrington-Smith, Towards a Plan for the Tugela Basin (Town and Regional Planning Commission, Pietermaritzburg, 1960), p 111.

2. A. Christopher, "Natal, A Study in Colonial Land Settlement", PhD thesis, University of Natal, 1969.

3. J. Tempelhoff, "Time and the River: Observations on the Vaal River as Source of Water to the Witwatersrand, 1903-24", Historia, 46(May 2001), pp 247-270.

4. L. van Sittert, "The Supernatural State: Water Divining and the Cape Underground Water Rush, 1891-1910”, Journal of Social History, (2004), pp 915-937. 
Visser, citing Freund, ${ }^{5}$ contextualises the slightly later engagement with water projects as being significantly politicised, and describes in detail the role in which water was considered as an agent for social change. ${ }^{6}$ Visser's work is reinforced by Themba Middelmann, who acknowledges the origins of the planning for the Hartebeespoort Scheme as being prior to Union, although the major works were carried out after 1910 and were influenced significantly by the Carnegie Commission. ${ }^{7}$ This project, together with others such as the semi-paramilitary project at Pongola in the early $1930 \mathrm{~s}^{8}{ }^{8}$ thus had a significant social engineering aspect. However, with the Winterton Irrigation Settlement, scant evidence exists suggesting poverty alleviation as per the above schemes. Instead, the deliberate and stated intention was to break the stranglehold of the large landowners who produced little food, and to open up lands to more modest farmers, broadening access to a variety of types of agricultural production.

This article thus considers water provision from a slightly different angle: the provision of a significant (and "cutting edge") infrastructure in an area remote from markets and industry. Further, brokering a socially sustainable project which, once authority and ownership was assumed by its tenant farmers, has endured for a century, it treads on the territory of development studies and supports relatively recent constructs such as social sustainability. Thus, while fundamentally the provision of infrastructure is a critical part of human expansion and development, and underpins the potential of places and their inhabitants, in a water-scarce country such as South Africa, the provision of infrastructure delivering potable drinking water is vital and evident. On a more invisible level is the need to regulate water supply to buffer food production in times of water scarcity. Whilst this paper acknowledges the significant body of work on water projects in other regions, consideration is rather on the actual provision of the infrastructure, in addition to using the contemporary lens of social sustainability to understand why the original project is still operational today, while many others, such as the initial Pongola scheme, have failed.

In the individual colonies that currently comprise South Africa, the issues of water, conservation of water and access to water are long standing and tied firmly into the greater conservation debate. In the early 1990s, Richard Grove described the nineteenth-century theory of "dessication" which linked deforestation, change in rainfall patterns and climate change. Thus our national discussion on water and climate change is not new, as the sources that Grove cites were part of the imperial

5. W. Visser, "Water as Agent for Social Change, 1900-1939: Two Case Studies of Developmental State Approaches in Establishing Irrigation Schemes", Historia, 63, 2 (2018), pp 40-61.

6. Visser, "Water as Agent for Social Change", p 44.

7. T.J.D. Middelmann, "The Hartebeespoort Irrigation Scheme: A Project of Modernisation, Segregation and White Poverty Alleviation, 1912-1926", South African Historical Journal, 67, 2 (2015), pp 158-179.

8. D. Whelan, "Special Services Battalion of Lands", forthcoming paper. 
period, and derived from the implementation of forest preservation in Mauritius in 1867. ${ }^{9}$ Significantly, Harald Witt records that,

... as the global expansionism of European interests continued, further evidence of soil erosion and deforestation was encountered. These observations of environmental degradation were recorded by a variety of colonial administrators and scientists, who witnessed at close hand the destruction caused by colonial expansionism, especially the denudation of previously wooded areas. ${ }^{10}$

He goes on to explain that this discussion naturally trickled through to the Cape Colony, in which severe droughts in the 1820s, 1840s and 1860s "provided major catalysts for state intervention".11

These observations culminated in the Forest and Herbage Act, No. 18 of 1859, passed in the Cape Colony, which at the time governed the colony of Natal. The environmental discourse, a fundamental component of contemporary sustainability, was thus well underway by the beginning of the twentieth century in the colonies comprising the contemporary South Africa.

William Beinart considered these environmental challenges in his significant work on conservation in South Africa. ${ }^{12}$ However, whilst as a child of the Cape Colony Natal was included in the general colonial decisions and discourse, it had its own challenges such as rapid expansion; a necessary alienation of land towards the end of the nineteenth century in order to raise funds; and a stated social and political need to make this land useful.

Following the Cape, a brisk series of ordinances and proclamations relating to land use and conservation were promulgated in the Natal Colony at the end of the nineteenth century. ${ }^{13}$ Such official interventions did not, however, prevent a number of devastating natural events at this time, one of which was a significant and extended drought at the beginning of the 1890s. Calamities such as this impacted severely on the economy of the young colony, particularly its access to stable food sources. Together with locust plagues and the rinderpest, water, lack of water and access to water were contributory factors in the change of social relations in colonial Natal, and had subsequent effects on those in the Union of South Africa after 1910. It was

9. R. Grové, in H. Witt, “An Economic, Social and Environmental Study of Afforestation: A Case Study of Tree Growing in Natal 1900-1960", MA dissertation, University of Natal, 1996, p 25.

10. Witt, "An Economic, Social and Environmental Study of Afforestation", p 25.

11. Witt, "An Economic, Social and Environmental Study of Afforestation", p 28.

12. W. Beinart, The Rise of Conservation in South Africa: Settlers, Livestock and the Environment, 1770-1950 (Oxford University Press, Oxford, 2003).

13. C. Marwick, "KwaMahlathi: The Story of Forestry in Zululand", Bulletin No. 49, Department of Forestry, Pretoria, 1973, p 7; and J. Lambert, Betrayed Trust: Africans and the State in Colonial Natal (University of Natal Press, Pietermaritzburg, 1995). 
recognised that judicious control of water resources allowed for more practical, diverse farming which could offer better food options, and be more resilient in the face of environmental adversity.

It is important to note at the outset that the Winterton project was driven by the Natal colonial government in order to settle tenant applicants on the property, subject to the rules and conditions of settlement which included demonstrable effective crop production. It presupposed willing settlement by applicants, all of whom were white settlers of a common socio-economic background, and it was intended that they would be joined by fresh immigrants from England although many of the applicants were from the Cape. At the same time, this project differed markedly from some of the other British colonial-era developments such as those at Gezira in the Sudan, in which tenant farmers (not colonial immigrants but local Sudanese) were inveigled into crop production on lands between the Blue and the White Nile from 1910 until around 1950. Maurits Ertsen argues that the concept of development in this instance failed dismally from an imperative and distanced view, but also that it "continues to be in use to date". This endurance has vital relevance in the discussion of the Winterton Irrigation Settlement, which continues similarly to operate, but on a modified level and not subscribing to the original intentions of the authorities. ${ }^{14}$ The similarity between the constructed irrigation settlements at Gezira and Winterton is noted, suggesting that an inevitable potential for both settlements existed, but that the actual unconscious continuity was driven more by an internal social force rather than an externally imposed set of imperatives.

This continuum thus points to a locally generated social network as the main operating framework for the continuity of the project. Whilst a relatively new sibling in the sustainability debate, social sustainability was tackled at the outset by Stephen McKenzie, who arrived at a succinct explanation in which "Social sustainability is a positive condition within communities and a process within communities that can achieve that condition". 15 Necessary pre-existing conditions which allow socially sustainable environments to operate and perpetuate are supported by social and cultural cohesion, a sense of ownership reinforced by a common ability to identify needs, articulate them, and act on them. McKenzie suggests that equity between generations is vital, preventing future generations being hampered by decisions made in the present and also transferring the notion of social sustainability. Bearing these qualities in mind is useful then, in assessing the social sustainability of the Winterton Irrigation Settlement which is fundamentally underpinned by the environmental and political conditions which allowed for its development.

14. M. Ertsen, "A Matter of Relationships: Actor Networks of Colonial Rule in the Gezira Irrigation System, Sudan", Water Alternatives, 9, 2(2016), pp 203-221; and Thorrington-Smith, Towards a Plan for the Tugela Basin, $\mathrm{p} 111$.

15. S. McKenzie, "Social Sustainability: Towards Some Definitions”, Working Paper No. 27, McGill Hawke Research Institute, University of South Australia, 2004, p 23. 


\section{Irrigation schemes}

Late nineteenth-century farms in the interior, distant from the main market in Pietermaritzburg were large, originally Voortrekker allocations of around 6000 acres intended for running cattle, or else purely speculative and occupied by rent-paying tenants. At the same time, most of the fresh produce in Natal was supplied to colonial settlers by viable African market gardeners from Amakholwa communities such as Georgetown in Edendale and its outstations. In addition, large groups of settled people such as the Hlubi under Langalibalele in the Estcourt district provided food. ${ }^{16}$ This situation changed with the dispersal of the Hlubi location in 1873 after the Langalibalele Uprising and was exacerbated by the aforementioned environmental calamities at the end of the nineteenth century, followed by the devastation wreaked by combat in the South African War. For the newly constituted Natal parliament, a coordinated strategic approach to food production at official level was at the time nonexistent, but becoming increasingly necessary.

After the South African War, the new parliament realised that there was now a significant difference in both imperative and scale, in the requirements for irrigated land. The lack of locally-grown food and selfish use of farmlands, led to the Natal colonial government developing new settlement models as well as the concomitant planning initiatives for water use in the colony. The most successful of these was that centred on Winterton, which involved the construction of two primary furrows flowing some $30 \mathrm{~km}$ roughly parallel to the Tugela River, completed in 1905. Apart from the significance of the provision of infrastructure for damming, controlled water supply and its dispersal maximising the potential for agriculture, this project also had a remnant social engineering aspect. Similar to its immigration settlement precedents, ratification through the official channels ensured that the applicants for the lands were intended to be small-scale farmers. On application, their access to landholdings in the Natal Colony was limited through conditions, thus calling for applications for a "different class of farmer" intended to break the stranglehold of the large landholders in the colony. This included not only those large properties lying fallow and often hosting a large number of African tenants or "squatters", but also those in the hands of speculative companies such as the notorious Natal Lands and Colonisation Company which had thousands of acres of unused and fallow land locked up in ownership. ${ }^{17}$

While previous schemes such as those at Umzimkhulwana, Umzinto and the duplicate irrigation scheme at Weenen were in use with varying measures of success, their different scales of infrastructure, intake potential and extent of furrow are indicative of their respective time of construction. At the same time, their individual circumstances also reveal a developing capacity for understanding the specific farming conditions, and needs in the Natal Colony, ${ }^{18}$ and as a result, highlight the

16. N. Etherington, Preachers, Peasants and Politics in Southeast Africa, 1835-1880 (Royal Historical Society, London, 1976), p 117.

17. Lambert, Betrayed Trust, pp 86-91

18. Christopher, “Natal, A Study in Colonial Land Settlement”, pp 138-141. 
commitment of the authorities to the Winterton scheme and its position in late colonial engineering works.

Common with all of these schemes is that there is limited source material. Given the sheer practical nature of the farming operations, and the physical "carved out" negativity of the furrow, there is little by way of secondary source material which deals with the conception and settlement of this scheme. Thus, recourse has largely been made to A.J. Christopher's 'Natal, A Study in Colonial Land Settlement' (1969), given its broadcast and contextualised assessment of colonial settlement in the former Natal Colony. Some references in publications exist: The colonial "brochure" Twentieth Century Impressions of Natal published by Lloyds in 1906 acted largely as a marketing tool for immigrants and this volume describes the irrigation settlement in glowing terms. ${ }^{19}$ This is reinforced by the official advertising leaflet lauding the project at the time of its launch in 1905, given its detail, descriptions and promises. Thus, with the dearth of work in the published domain, much of the source material in this article has been gleaned from archival material based at both the KwaZulu-Natal Provincial Archives Repository in Pietermaritzburg, as well as the National Archives Repository located in Pretoria. Further, given the position of this settlement as primarily politically-initiated and critical for the expansion of crop production, for the most part the files in which source material is found are related to the interface between the contractor, the farmer and officialdom. While these personal voices predominate, given that the control of water is governed by public gazette, legislations, ordinances and Government Gazettes also form part of the primary source material.

The contextual information with regard to general environmental conditions and problematic access to food in late nineteenth-century Natal has been described. This article will proceed to set out the political processes that led to the legislated declaration of the Winterton Irrigation Settlement, before relating more closely the means by which access to the lands on which it was situated was achieved.

\section{The formation of the Land Board}

Moving quickly, the Natal colonial government reacted to the food crisis after the South African War with alacrity, by appointing G.C. Williams to lead the investigation. An engineer who had worked in the colony for some time, Williams provided input into siting irrigation settlements along the Tugela, ${ }^{20}$ whilst the Natal parliament engaged with the legal aspects. These led to Act No. 24 of 1902, enabling parliament to establish a Land Board which had the powers to purchase properties for settlement. This would allow them to implement the required denser and more

19. Lloyd's Publishing, Twentieth Century Impressions of Natal (Lloyds Greater Britain Publishing Co., London, 1906), p 594.

20. KwaZulu-Natal Provincial Archives Repository (hereafter KZNPAR): Parliamentary Minute (hereafter PM) 41 3239/02, G.C. Williams forwards report, 3 November 1902. 
efficient farming strategies, in order to diversify food production and to some degree, satisfy the political ends of expanding white settlement. ${ }^{21}$

Prominent colonists were appointed to the Land Board. This was based on the assumption that such men were well versed in the farming methods and conditions of the colony. Their terms of reference were to establish the extent of the remnant crown lands in the colony not allocated through grant or quitrent, and to identify those properties that had been allocated, but were not being sufficiently occupied in terms of the original grant. These were assessed with respect to their potential for general agriculture, grazing, and irrigation settlements, and with this information, the members of the Land Board were compelled to submit proposals to the colonial authorities for purchase or expropriation. ${ }^{22}$ In addition, they controlled access to any newly alienated land through settlement schemes in that they assessed applications, chose incumbent tenants and ensured the correct implementation of the scheme. Further, they had the powers to adjudicate applications for financial advancements to settlers, where necessary.

The Land Board was appointed on 7 November 1902 in terms of Act 24 of 1902. It consisted of four members from prominent farming families. James Kirkman from Umzinto and Leonard Acutt from Tongaat both had a sugar production background, whereas James Morton of Tweedie Hall and John Moor of Mooi River had mixed farming backgrounds. ${ }^{23}$ E.T. Mullins, secretary to the Hon. Henry Winter, the then minister of agriculture, acted as administrative correspondent; H.W. Armstrong served as secretary; and James Morton was elected as the chairman. From correspondence at the time, it would appear that the legislation regulating earlier closer settlements in Natal under the old Cape Colonial law was flimsy to say the least. This expanded the duties of the new Board which entailed visiting similar officiallysanctioned settlements such as those at Fort Nottingham Town lands. This experience was evidently desultory which led to the dramatic declaration that "the Board is satisfied that the present (casual) state of affairs is neither good for the settlers nor for the Colony". Thus, for the intended Upper Tugela Irrigation Settlement (later the Winterton Irrigation Settlement) “... the Board recommends that a Department or Board should be constituted for the purpose of managing, controlling, and taking over

21. Although this forum was established on 7 November 1902 under the provisions of Act No. 24 of 1902, it was ultimately fully enabled through the promulgation of the Agricultural Development Act, No. 44 of 1904. However, operations devising the project were contiguous to the formation of the legislation. Effectively, political drive allowed for rapid design and implementation of the project, and allocation of lands for settlement. See KZNPAR: PM 41 3104/02, Appointment of Board, 15 October 1902.

22. KZNPAR: 41 1696/03 Appointment of Land Board 3104/02, 15 October 1902

23. KZNPAR: PM 41 3104/02, Appointment of Board, 15 October 1902. Note that this document records the appointment of Kirkman, Moor and Morton with $\mathrm{Mr}$ Abrabrelton as secretary, whereas the official marketing pamphlet: The (Natal) Land Board, The Winterton Irrigation Settlement, Natal (Times Publishing, Pietermaritzburg, 1905), records the names of the members. Also see KZNPAR, PM 41 3104/02, Appointment of Board, 15 October 1902. 
all the details connected with the above settlement". ${ }^{24}$ This laissez faire approach is significant in the gap between management at authoritative level, and the means by which the settlers eventually positioned themselves as a thriving community in the absence of official control.

Despite the initial absence of the specific legislation allowing for the development of irrigation settlements, the Land Board moved forward with the original mandate of sourcing land and recommending sites for the intended settlement. The focus was on the waters of the upper Tugela River, which has its source in the northern Drakensberg and flows northeast to the Indian Ocean. At the time of consideration, the farmlands through which it flows consisted mainly of old Boer lands, granted to the 1838 Voortrekkers who settled in this area, as well as territory laid aside for African settlement in locations. Many of these farms were owned at the time by absentee landlords, who controlled numerous other tracts of land, one of the more significant being the Natal Lands and Colonisation Company. ${ }^{25}$ These farms were central to field action during the South African War of 1899-1901, and their subsequent denser settlement by means of the irrigation project could have only been strategically advantageous for the colonial government.

The surveys showed that suitable crown lands no longer existed; this meant that the colonial government had to choose lands already alienated and motivate for their purchase. Three properties formed the kernel of these irrigation lands. On 3 November 1902, Williams advocated for the purchase of the contiguous farms Deel Drift, Nooitgedacht and Kerkplaats, all situated on the Tugela. ${ }^{26}$ Although extinct as whole properties today, these formed the parent farms on which present day town of Winterton is located.

Williams carried out extensive feasibility studies to motivate for this scheme. At the time of the land acquisition proposals, he estimated the costs of the irrigation scheme at $£ 21500$, in addition to a bridge across the Little Tugela at a potential cost of $£ 3000$, and three miles of fencing with gates. Further, he advocated for a narrow gauge railway, all ancillary requirements in the economic sustainability of the project. ${ }^{27}$ The infrastructure had to allow for a sustainable settlement, particularly ready access to markets.

A brief history of these properties and the means by which they were acquired will contextualise the discussion to follow, since their scale indicates the extent to which the fragmentation into lots for the Winterton Irrigation Settlement is an important diversion of landholding and farming potential in the district.

\footnotetext{
24. KZNPAR: PM 41 1323/03, First ad interim Report, 8 May 1903.

25. Lambert, Betrayed Trust, pp 86-91.

26. KZNPAR: PM 41 3239/02, G.C. Williams forwards report, 3 November 1902.

27. KZNPAR: PM 41 3239/02, G.C. Williams forwards report, 3 November 1902.
} 


\section{The properties and their purchase}

The farm Deel Drift straddling the Tugela River, was an ideal purchase. Prior to British annexation, it was granted to Evert Frederick Potgieter and Salomon Marits through Voortrekker grant. Subsequently it was granted to Pieter Zeederberg in 1849 for which he paid some 1500 Rijks dollars. ${ }^{28}$ Certainly, at the time of its original survey in 1852, the appended "Report on Lands Measured" records that its surveyor, George Martin, considered it a "First Class farm" of some 8272 acres. It was then purchased by the Natal Lands and Colonisation Company, through Zeederberg and others in 1852. At the time of its purchase by the government in 1902, the Natal Lands and Colonisation Company was in financial difficulties and selling such land assets was a necessity. Whilst the archival records indicate that there were extensive negotiations in this transaction, the colonial government was determined and eventually the lands passed into the authorities' hands.

The other properties were in private hands and also subject to negotiation. While land register information for Kerkplaats is missing, Nooitgedacht belonged to a member of the Hatting family who was a significant landowner in the area. ${ }^{29} \mathrm{~A}$ little haggling ensued in which official documentation records that "... ministers expressed the opinion that the Minister of Agriculture should endeavour to come to terms with Mr Hatting for the purchase of the farm Nooitgedacht". ${ }^{30}$ By 2 December 1902, this had been arranged at a price of 40/- per acre. A fourth farm, Varkensfontein was also part of the discussions, but its purchase came to naught for the direct purposes of this project.

Sales for the initial properties were completed quickly, intimating little resistance to their purchase for denser settlement. In May 1903 the first ad interim report was submitted by the Land Board discussing, among other matters, the "Upper Tugela District Irrigation Scheme" which recommended that the farm Strydpoort also be purchased, since this was ideally placed to dam water for reservoir purposes. ${ }^{31}$ The Board stressed in this report:

... that all lands under the different schemes submitted in the Report should be held under well-approved 999-year leases and that the fixing of rentals should be one of the duties of the Board. In no case should title be parted with by the

28. KwaZulu-Natal Department of Rural Development and Land Reform, Deeds Office (hereafter Deeds) Undated handwritten note by J. Maritz in Dutch on Grant Deed, No. G1139/1849.

29. Deeds, Grant G837/1857 and Land Register for Doornkop 837, Jacobus Hatting purchased Doornkop from George Piggott Moodie in 1868. By the end of the nineteenth century his family members owned substantial holdings in the district.

30. KZNPAR: PM 41 3239/02, Purchase of Nooitgedacht, 20 November 1902.

31. Note that the topocadastral map for 2829DC for 1944 does show a relatively small holding dam on Strydpoort. 
Government, and care should be taken to prevent leases from falling into the hands of undesirable persons. ${ }^{32}$

While the purchase of Strydpoort appears to have fallen through, more urgent was the actual construction of the project and the logistics involved therein, given its isolation from the urban centres and the urgency to settle new farmers on the land.

\section{Engineering the Winterton Irrigation Scheme}

The amalgamation of the three parent properties of Deel Drift, Kerkplaats and Nooitgedacht focused on the irrigation settlement. Whilst initially named Springfield, it was later renamed Winterton after the then minister of agriculture, H.D. Winter. The present day town is situated about $140 \mathrm{~km}$ from Pietermaritzburg, and even today, is a village on the periphery of the province and situated in the middle of farmland. Given the remoteness of the site, the Land Board required a co-ordinating agent who could deliver a project of this magnitude. Williams, the engineer who had carried out the initial feasibility study, was awarded the contract. He had worked for the colony as a surveyor for two decades and had a good reputation, having been involved with other water schemes, particularly the furrows at Weenen, in addition to a proposed irrigation furrow leading from Howick Falls to the city of Pietermaritzburg some years before. ${ }^{33}$ Indeed, his role in water infrastructure provision in the late nineteenth and early twentieth century is significant in the water history of present day KwaZulu-Natal.

His pivotal role as a core member of the team in the early planning stages has been noted. ${ }^{34}$ Even before the promulgation of the 1902 Act allowing for the development of the settlement, as the engineer-in-charge of implementation he was responsible for the large-scale planning: the costs of the development proposals had to be off-set against potential leases for allocation. From the outset he required a full understanding of the complete final costs which involved a tight rein on the budget. Williams considered it vital to prioritise the survey of the lots in the immediate proximity to the intended settlement and grade them according to their farming potential, in order that rental income on the properties was forthcoming as soon as possible. A systematic survey of the town lots and the farms in the irrigation settlement thus accelerated potential income. This needed to be balanced against realistic tenders for operations, contractors for the furrows and other engineering works, as well as projected ancillary infrastructure requirements which would make the village and the settlement in general, viable.

32. KZNPAR: PM 41 1323/03, First ad interim Report, 8 August 1903. It is suspected that 999 years is a misprint. Three decades later, gazetting of the Winterton Irrigation Scheme allowed for permanent freehold grants to this land.

33. KZNPAR: Colonial Secretary's Office (hereafter CSO), 1239 1889/6420, G.C. Williams asks for the co-operation of the government in his efforts to ascertain whether an irrigation canal could be brought from the Umgeni Waterfall to the Maritzburg basin.

34. KZNPAR: PM 41 1870/1903, Minute to the Minister of Agriculture from G.C. Williams, 8th September 1904. 
William's design allowed for two irrigation furrows of nearly $30 \mathrm{~km}$, leading off a new concrete weir on the Little Tugela River. He considered a new engineering form for the weir using an ogee arch, also known as a "Rollerway" (See Figure 1).

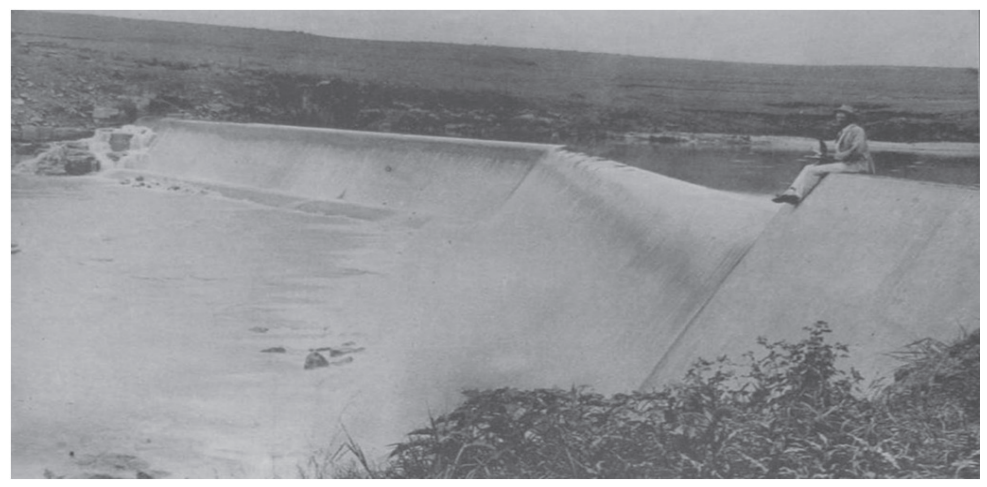

Figure 1: "Rollerway" weir at Winterton shortly after construction ${ }^{35}$

The use of cement to form structural concrete at the time was significant, given its scarcity and cost. ${ }^{36}$ Williams estimated that the weir and the furrows could irrigate about 5000 acres. However, given the costs involved, this infrastructure was at the time complex and difficult to deliver. The main furrows were to run adjacent to the Tugela, with myriad changes in direction in order to maximise the extent of the lands for irrigation. From the main furrows, sub-furrows would lead off to spread the water over a greater area. Its design was not capricious. In a report to the minister of agriculture, Williams described the furrow as running at a 1:3000 fall, saying that it,

\begin{abstract}
... appears in practice to give the full velocity given in theory + with our sectional area of furrow i.e. 45 sq. $\mathrm{ft}$. should be fully capable of supplying the quality of water necessary for correct irrigation of 5000 acres + the only uncertain factor in the whole scheme is the flow of the river in our dry seasons. ${ }^{37}$
\end{abstract}

This rather exacting exercise was to be executed using draught oxen, ploughs, and paid manual labour.

Setting up the preliminary works occurred rapidly. The colonial government had barely completed the purchase process of the properties in January 1903 when the project began. ${ }^{38}$ Williams reported to the minister in May 1903 that he had

35. Land Board, Winterton Irrigation Settlement.

36. KZNPAR: PM 41 1870/1903, Report to Minister of Agriculture from G.C. Williams, 1 January 1904.

37. KZNPAR: PM 41 1870/1903, Report to Minister of Agriculture from G.C. Williams, 8 September 1904.

38. KZNPAR: PM 41 1870/1903. The colonial government had completed the purchase of Deel Drift and Kerkplaats by the end of 1902 and was only then given the go-ahead to 
installed his assistant, a Mr Bennet, in the old farmhouse on the farm Nooitgedacht. This property was in a state of dereliction, and required extensive work in order to make it liveable as well as forming the core of the development of the scheme. Remedial work included repairing the turbines and the mill, and ploughing the soil in order to grow crops to subsidise the costs of running the project. In addition, both stock and labour required feeding. Furthermore, Williams had pegged out the initial furrow, supervised the excavations for the foundations of the weir and had monitored the concrete mix and pour. Other maintenance issues around the property were also addressed, such as repairing fences and burning firebreaks to preserve the winter grazing for the mules and the eight oxen required for the engineering works. ${ }^{39}$

Frequent communication in order to run the project was expedited through the provision of telephone cables between the fledgling irrigation settlement and the rest of the colony. Running the actual engineering works too, had to be carefully coordinated. A Mr Woods was appointed to construct the furrow and a man called Reynolds won the tender to carry out the concrete construction on the weir. Given that most of the necessaries would have to come from Pietermaritzburg, a transport rider also had to be engaged and this tender was won by a Mr De Waal. Such logistics being completed, at the time of the award of tender in April 1903, Williams optimistically anticipated the project taking a year to complete. This was not to happen. ${ }^{40}$

While Williams had feasibly considered all the options, the project was beset by constant challenges. Commenced in June 1903, the efforts of the contractor were hampered by issues not factored into the original proposal - such as drought, heavy rain in February 1904, and from time to time hard and rocky ground which required re-design. The furrow contractor, Woods, through Williams, complained constantly about the lack of labour as he had established that people did not want to work for wages and rations. This had been an assumption in the original planning. Delivery of materials too, was problematic. A siphon pipe to carry the furrow across the Pretoriusspruit, a small tributary, was ordered from England and delay in its arrival held up the works. It eventually arrived at the end of May 1904. ${ }^{41}$ Furthermore, constructing bridges and crossing erosion gullies involved engineering solutions and co-ordinated action, all of which was closely documented. By January 1904, just over six months into the contract, Williams was able to report that the work was all but completed.

purchase Nooitgedacht. By January 1903 the purchase was completed; by April 1903 the tenders were received and by June, ground was broken on the furrow. See Minute from Minister Winter to the Prime Minister, 12 May 1903.

39. KZNPAR: PM 41 1870/1903, Report to the Minister of Agriculture from G.C. Williams.

40. KZNPAR: PM 41 1870/1903. See comments in the report to Minister of Agriculture from G.C. Williams, 31 March 1904.

41. KZNPAR: PM 41 1870/1903, Report to Minister of Agriculture from G.C. Williams, 29 May 1904. 
As previously indicated, the weir had been finished as had part of the intake of the furrows. Furthermore, at the time of submitting his report, the weir had already endured two floods - one of two feet and another of nine inches. Williams recorded in detail Woods' logistical issues in completing the main furrow, in which its intake from the weir was positioned far deeper than expected, which entailed breaking through hard rock. In this report, Williams estimated that the unanticipated work this entailed would set the project back three months. In order to mitigate this delay, he extended the contract with Mr Reynolds, the contractor for the weir, and another contractor, a Mr Palframan. ${ }^{42}$ Williams also reported on the "small furrow", noting completion of two of the four road bridges; that he was still awaiting the arrival of the siphon; and that his team had completed the renovations to the caretaker's house. ${ }^{43}$

Only in September 1904, could Williams see the light at the end of the tunnel. He recorded in his report to the minister of agriculture that:

The only thing that now remains to make the Winterton Irrigation Scheme a success, is the placing of 66 capable working families on the land + the establishing of a village with easy means of communication with the main line.

He went on to report that he had completed his survey of the plots forming the larger settlement, adopting a principle that the layout of the lots had as many similar properties as possible,

... every lot must be capable of being watered without having to run water over any other lot. Next access to our bridges over furrow + in many cases routes of roads had to be laid down to existing drifts with easy grades to minimize expense of construction, so that in many cases blocks of land were bounded on all sides by roads, river, and furrow - these naturally could not always work out at 60 acres each, but I think you will agree with me when I say I have never strayed from your limits. ${ }^{44}$

Woods, the earth works contractor, was particularly disadvantaged by the delays, and ended up completing his section of the works nearly a full year overdue, in February 1905.45 In this particular report to the minister of agriculture Williams was able to report at length on the status of the project. Woods's contract had been fraught with problems, which required constant intervention by Williams. Apart from furrows silting up and sheet metal flumes needing to be inserted, there were a number of unexpected obstacles that had to be solved. Williams reiterates in this missive the issues of labour shortages. More abstrusely, as the result of extreme climatic events in

42. KZNPAR: PM 41 1870/1903, Report to Minister of Agriculture from G.C. Williams, 1 January 1904.

43. KZNPAR: PM 41 1870/1903, Report to the Minister of Agriculture from G.C. Williams, 1 January 1904.

44. KZNPAR: PM 41 1870/1903, Report to Minister of Agriculture from G.C. Williams, 15 February 1905.

45. KZNPAR: PM 41 1870/1903, Report to Minister of Agriculture from G.C. Williams, 15 February 1905. 
1903 and 1904, an unanticipated shortage of mealie meal was also a factor in holding up the project, as it was an essential requirement to feed the labourers employed on the project. Mealie meal had simply become excessively expensive. ${ }^{46}$ Furthermore, drought had made the ground very hard to work, and as he notes, this

... made working with oxen almost impossible + as the whole or at least $95 \%$ of the work has been done with ploughs + [unreadable] + [unreadable] this was a great hindrance + extra expense as [I] had to feed the oxen the whole winter. ${ }^{47}$

Added to this, was the series of unanticipated and thus unbudgeted, variation orders to the works. Initially Woods had a contract to complete about $18 \frac{1}{2} 2$ miles of furrow but two deviations arose "to render donga crossings safe"; one of these included 1 500 cubic yards of shale, and the second 500 cubic yards of sandstone. A third deviation from the original tender was a mile and a half of secondary furrow constructed along the Deel Drift boundary. Further, following the flooding of 1904, Williams found it necessary to create some extra drainage furrows to alleviate the stress on the main furrow, these leading through a more percolate "black soil" amounted to a total of an extra three miles. In a nutshell, Woods had carried out a prodigious amount of work as an extra allocation above and beyond his original contract.

\section{Laying out the allotments}

At the same time as supervising the engineering works, Williams's task also included laying out the village at the centre of the irrigation settlement. For for this he allocated approximately 105 acres and split the area into 46 erven (plots) of around half an acre each. ${ }^{48}$

The imperative to allocate lands for settlement and garner rental income was based on a specific social and economic framework guiding the selection of tenants. While the required lands were still being purchased, the Agricultural Development Act No. 44 of 1904 was promulgated which allowed for surveying and laying out plots. ${ }^{49}$ The stated intention of this legislation was "securing for Natal ... an industrial

46. KZNPAR: PM 41 1870/1903, Minute from Minister Winter to Prime Minister, 12 May 1903.

47. KZNPAR: PM 41 1870/1903, Report to Minister of Agriculture from G.C. Williams 15 February 1905.

48. KZNPAR: PM 41 1870/1903, Report to Minister of Agriculture from G.C. Williams, 8 September 1904.

49. This was followed by other acts of the Natal parliament which backed up the initial legislation and refined it as the extent of the properties grew and the scope of land ownership changed. At the outset, following on the 1904 legislation, Act No. 39 of 1908 and Act No. 8 of 1909 both dealt with the establishment of the Winterton Settlement specifically and Varkensfontein, closer to the town of Colenso. Later, Act No. 16 of 1926 was promulgated to "... provide for the Constitution of a Local Board of Management for the Winterton Irrigation Settlement, County of Weenen in the 
and farming population", in addition to breaking the stranglehold of large tracts of farmland being locked in the hands of single owners, as had the parent farms been under their previous owners. This requirement led to the legislation limiting the size and number of applicant's alternative landholdings. It also restricted their tenancy on the Winterton lands to no more than one tract of irrigated land and one tract of "dry" land. Lands for allocation were classified into categories: first class for special farming, second class for mixed farming and third class for "pasture or tree planting". 50

These properties were subject to leases, in which the third class lands were leased for 33 years, and first and second class lands for 99 years. The lessees of the latter two classes were obliged to live on their farms for at least nine months of the year, and effect what were loosely described as "improvements" on them. Furthermore, it was stressed to potential settlers that the lands were not, at the time, freehold but only intended for rental purposes. The Land Board also intended to provide infrastructure for development of the lands in and around the settlement.

The first class lands were those closest to the irrigation area and were typically intended for division into "blocks for irrigation areas, small dairy, poultry, or bee farms or the like, the cultivation of fruit, tobacco, fibre plants, essential oil plants, vegetables, or any other agricultural products of high market value". This intimated mixed farming methods, expanding the agricultural potential of the colony. These allocations were then subject to the following sub-stipulations, in that the lots were then divided accordingly. AS the Act put it, those "intended for irrigation shall be divided into lots not exceeding 60 acres each, save where the quality of the soil renders some extension advisable ... Blocks not intended for irrigation shall be divided into lots not exceeding 250 acres". ${ }^{51}$

Second class lands were offered on a 99-year lease; these were intended for more intensive agriculture. They were typically of 250 to 500 acres, and had a firm residential requirement for at least nine months in a calendar year. This stipulation reflected the real economic situation of the tenants. Many farmers were absentee landlords because they obtained their primary forms of income not from farming, but from transport riding. Thus, this clause stimulated settlement, was relevant, and not considered as prejudicial.

Province of Natal, to amend Act 39 of 1908 of Natal and to provide for certain incidental matters".

50. Of interest is that in the initial survey of these farms in the 1850s the extant verdant landscape consisted largely of "mimosa" vegetation - a means of describing the acacia thornveld of the area (See Title Deeds, "Reports on the Lands Measured").

51. Natal Colony, Agricultural Development Act, No. 44 of 1904, p 94. 
Those third class lands subject to shorter leases of 33 years on "dry" farms were deemed suitable for forestry or grazing. They could be further sectioned off into smaller plots of two acres each on a 33-year lease. ${ }^{52}$

These three components of the working settlement were conceived of, described and packaged at the same time as the engineering works comprising the settlement were in the process of construction. Ultimately, the parallel processes of design, legislation and marketing were as contiguous as any late twentieth-century development. Significantly, marketing the project was a key aspect in attracting the "right kind of settler".

By the end of February 1905 the lands were ready for settlement. The infrastructure had been provided, the irrigation lands had been laid off and the furrows completed, and the subdivision of the erven (plots) in the town of Springfield (Winterton) had been achieved. The next step was to place people on the farms in order that active farming take place, and that rental income could be realised by the colonial government to offset their expenditure as soon as possible.

\section{Marketing the settlement and allocation of lands}

The legislative imperatives appear to be firmly directed to a twofold scheme allowing for a more intensified and viable agricultural system, unlike the failed Byrne Settlement schemes at York, Byrne, and Verulam amongst others. These were limited by the extent of lands granted, in addition to the settlers being untrained in the requirements for viable agricultural production in the new colony. They did, however, participate in diversifying the colonial settler profile. In his work on colonial settlements in Natal, A.J. Christopher writes:

Unlike the settlement schemes of the 1850s, the [Winterton] scheme was not intended primarily as an attraction to immigrants from Europe, but rather as a means of providing for the agricultural community an increased number of farms in the hope of preventing the drift of population from the land.53

This is supported by a more direct imperative from the Prime Minister's Office in 1903 which notes of the Winterton settlement that it is,

... advisable that a Commission or Commissioners should be appointed by the Government, when the proposed Scheme is sufficiently advanced, to travel to Europe and there to select the most suitable immigrants it is possible to obtain, care being taken to select them from different European countries as well as from the United Kingdom. ${ }^{54}$

52. Indeed, all evidence in the Act points to the commitment of agricultural densification, since the government was prepared to take over timber farms on the expiry of the lease, in the event of the tenant not wanting to extend the commitment.

53. Christopher, "Natal, A Study in Colonial Land Settlement", p 175.

54. KZNPAR: PM 41 1870/1903, Minute from Minister Winter to Prime Minister, 12 May 1903. 
This directive strongly suggests a driven immigration scheme, which had the potential to diversify the white population and to draw more immigrants into the colony as small scale farmers. This theme was implicit in the manner in which the colonial government actively advertised the project.

Officially, the marketing was supported through a comprehensive pamphlet, The Winterton Irrigation Settlement, Natal. It was issued by the "Authority of the Land Board" and printed in Pietermaritzburg. It aimed to large degree, at encouraging the immigration and settlement of people resident in England, as well as other interested parties in the adjacent colonies. Its evocative and positioning statement attracting British colonials is evident in its description of the location as being "close to the historic battlefields connected with the relief of Ladysmith" in addition to a measured setting out of the climate, which "... in short, is one to which people from the British Isles can safely come without any injurious results so far as health is concerned". 55 The pamphlet reinforces the prime minister's imperative above. Its intention was quite blatant - to attract a "different kind" of settler through an immigration programme in which participants would actively farm and participate in the development of the land. This differed markedly from the extant situation in which absentee landlords owned large tracts of unproductive land. Instead, it allowed for a new scale of farmer. ${ }^{56}$

The document lauds the lands in question, laying out a series of viable options for farming, including tobacco, pigs, and bees, and the actual potential for these to be realised, saying that,

Settlers of the right class will, within a reasonable period be able to succeed in making a comfortable home with a fair prospect of starting their families in life; but, to do this, the Settler must be prepared to put forth the same energy and perseverance that he would were he situated on a farm of similar acreage in the Old Country. ${ }^{57}$

The pamphlet shows photographs of completed infrastructure, specifically the new weir on the Little Tugela River, the new bridge crossing the river, and typical homesteads with houses and water butts. It recommends the option of constructing wood-and-iron houses or sod structures, allocating a cost towards the building of these structures as a guideline for immigrant farmers. It also carefully compiles registers of costs associated with the acquisition of tools and farming implements and also lays out clear recommendations for settlers.

Advertisement for the scheme was not restricted to the pamphlet: the promotional volume, Twentieth Century Impressions of Natal (1906) pursued the agenda of the colonial government and recorded the following,

55. Land Board, Winterton Irrigation Settlement, pp 6-7.

56. Land Board, Winterton Irrigation Settlement, $\mathrm{p} 6$.

57. Land Board, Winterton Irrigation Settlement, $\mathrm{p} 8$. 
[The] Winterton Irrigation Settlement situated on the Little Tugela, in the vicinity of Springfield, takes its name from Mr Winter, the then Minister of Agriculture. The scheme was commenced in 1902 and completed in 1905, when the land was thrown open for settlement. The water is supplied by a furrow 18 miles in length from the little Tugela. There are now some 5000 acres under water, besides 12 000 acres of summer lands. That portion of the land which comes within the direct "sphere of influence" of the furrow is cut up into 66 blocks of about 75 acres each. Leases are only granted to persons of European descent, and are not offered for public competition. In every case, the Land Board decides, on receipt of applications, to whom any allotment shall be offered. A village has been laid out in a central position on the settlement, and sites are available therein on 99 years leases at annual rentals of from $£ 6$ to $£ 24$ a lot. ${ }^{58}$

After the furrow was opened and the irrigation waters set flowing, the Land Board commenced its work in earnest. It needed to allocate land to incumbent settlers through a careful vetting process, sifting its choices from a wide cross-section of applicants. The fundamental requirement was that all applicants had to be over 21 years of age. They were not allowed to own any other significant portions of land, limiting land speculation by existing landowners. They had to complete the official form which included, “... documentary evidence in respect to your capital and stock and a cheque for 15 pounds as a deposit on account of the probable charges for survey of land applied for". Subsequently, the applicant had to personally avail themselves in front of a committee which sat in Pietermaritzburg, in order to be able to claim these lands under lease. The Board assisted by offering a rail concession for settlers entering the colony from other regions to take up the plots. However, a rider to this concession noted that the "... concession applies over the Natal Section of the SA Railways only".59

Apart from not already being a rural landowner, the legislative constraints also prescribed that the applicant adhere to the 1887 Fencing Act, in addition to taking care of their stock with regards to disease.

Despite the original clauses allowing settlement on the lands with a 99-year lease, the leases signed by the allottees allowed them access to the land for a period of 22 years. The stipulations in the lease contained much the same conditions as most government grants at the time. The properties were allotted and quickly let, and actively settled to the extent that just prior to Union the official formation of the scheme was legally addressed in Act No. 39 of 1908 and Act No. 8 of 1909, both of which dealt specifically with the establishment of the Winterton Settlement.

58. Lloyd's, Twentieth Century Impressions of Natal, p 594.

59. Lloyd's, Twentieth Century Impressions of Natal. 


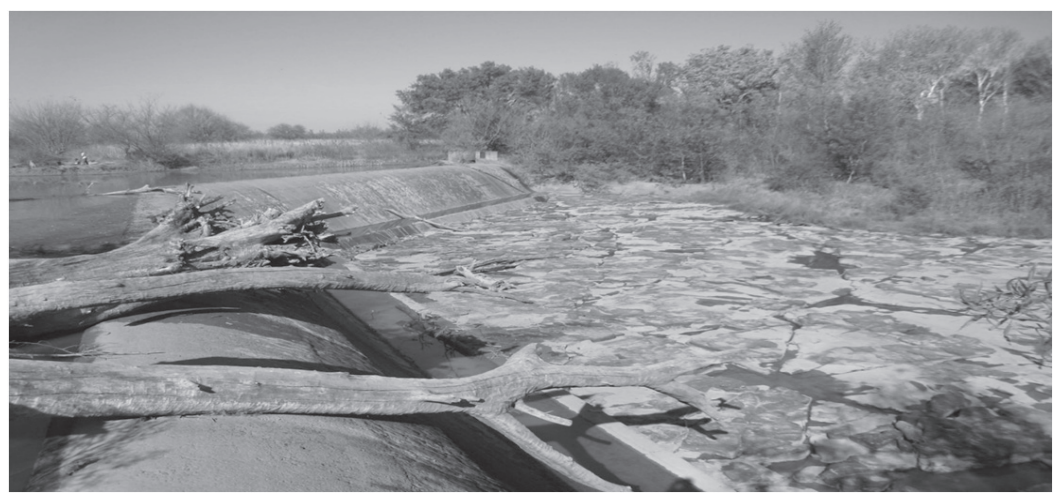

Figure 2: The weir today (photograph by the author, 2013)

\section{The ongoing viability of the Winterton Irrigation Settlement}

In the middle of February 1905, G.C. Williams penned a memo to the minister of agriculture of Natal noting no doubt with a measure of relief that "I have the honour to report the completion of the irrigation furrow (Wood's contract)". Significantly, Williams's note in February 1905 signalled the completion of a project which took less than two years to implement, but along the way was fraught with challenges and hardship. Tenders had been awarded in April 1903 and Woods completed his contract in February 1905.

By the mid-1920s the area around the Winterton furrows was prosperous and functioning well as a series of small, well irrigated farms. Unlocking water potential at a national level led to the Union government's promulgation of Act No. 16 of 1926 which was to "provide for the Constitution of a Local Board of Management for the Winterton Irrigation Settlement, County of Weenen in the Province of Natal, to amend Act No. 39 of 1908 of Natal and to provide for certain incidental matters". This Act effectively removed the administrative duties of the authorities and allowed for the creation of a new Winterton Irrigation Settlement Board, comprising members of the farming community, with a maximum of seven members, one of whom was to be appointed by the minister. ${ }^{60}$ Since then, Winterton has thrived as an agricultural community, enabled in large part by the two furrows that spread the river water across a greater landscape.

What had originally been stipulated in the ad interim report of May 1905 had changed significantly. Civil society, local management and appropriate communal regulation of water supply ensured that the Winterton Irrigation Settlement had the potential to endure as a programmatic response to basic infrastructural provisions and to function prosperously without the reins of official intervention.

60. Act No. 16 of 1926: To provide for the constitution of a Local Board of Management for the Winterton Irrigation Settlement, County of Weenen in the Province of Natal, to amend Act No. 39 of 1908 of Natal and to provide for certain incidental matters. 


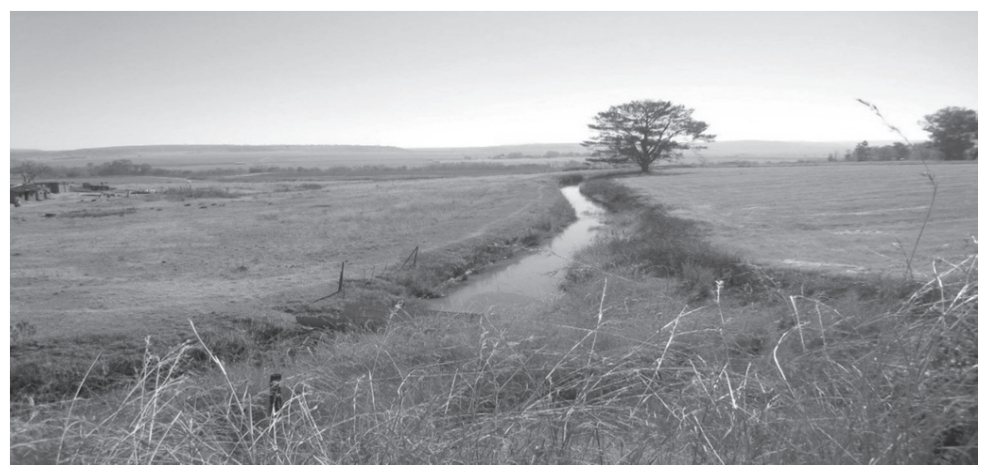

Figure 3: Winterton furrows (photograph by the author, 2013)

However, other forms of intervention emerged, which resulted in the much later amalgamation of water users. In conducting a holistic study of the run of the Tugela River and its water potential, E. Thorrington-Smith observed in 1960 that "Today Winterton cannot be regarded as an irrigation settlement in the usual sense of the term. So little use is made of the furrow water that the 80 acre farms may more properly be regarded as well watered smallholdings...". 61 The author refers to a mere eleven miles of furrow, whereas at the outset Woods reported nineteen miles. It also records covering an irrigation area of some 2300 acres, whereas at the outset, the intention was some 5 000. While the initial intention of the authorities dreamed of fruit production, in reality this proved unviable due to the high incidence of hailstorms. Thorrington-Smith reports that the properties were consolidated into the hands of a few farmers rather than the interesting diversity as originally hoped. Reflecting an ironic reversion to stock farming, with dairy herds and bacon pigs being produced, Thorrington-Smith comments that the irrigated pastures were utilised in the summer, but ensilage provided the food for the cattle in winter. ${ }^{62}$

Elements of this report eventually fed into the new National Water Act, No. 36, which was promulgated in 1998. Section 98 of this legislation made provision for transitional measures for the old water boards. A decade later, Gazette Notice No. 56 legislated for the amalgamation of the Winterton Irrigation Board into the Central Okhahlamba Winterton Water User Association, with its own constitution. This put an end to a self-managed system, incorporated within a social and economic framework, reliant on the furrows themselves to add a measure of cohesion to the local society.

\section{A century later}

Today, the Winterton Irrigation Settlement prevails. The furrows run, and the sophisticated water management system allowing for flexibility with respect to control of water implemented in 1905 is testimony to political imperative, social

61. Thorrington-Smith, Towards a Plan for the Tugela Basin, $\mathrm{p} 157$

62. Thorrington-Smith, A Plan for the Tugela Basin, p 157. 
negotiation, focused planning and dogged determination. Primarily, this paper intends to tell a story. It also aims to speak about the delivery of primary infrastructure, not a component of historical studies which usually address more strident issues and more prominent landmarks. Ultimately however, it discusses the means by which farming was partly diversified and property ownership was fragmented, allowing for a "different class of farmer" to explore the potential of small, irrigated farm cultivation, and succeed in achieving official requirements in diversifying crop production. At the same time, it addresses the perpetuation of a system under local control, communally accepted and managed, and sociallysanctioned and negotiated, in order to create a project with longevity rather than delivery. While parallels exist between the Sudanese Gezira project as described by Ertsen $^{63}$ the Winterton settlement is characterised by a commonality of land tenure, in which the settlers had an ethnically common origin and came from similar economic backgrounds, allowing for the positive condition of social sustainability. Social and cultural cohesion, a sense of ownership, a common ability to identify needs, articulate them and act on them are elements suggested by McKenzie.64 Further, the current-day landholdings by descendants of the original landowners suggests that equity between generations exists, allowing for the control of the infrastructure and the resources, to some degree being mitigated by the landowners and those with interest in the harnessing of agricultural land.

Christine Bichsel notes that "the relationship between the two components of infrastructure - the components Infra (meaning below, beneath or within) and the component Structure remain intriguing. The two components point to the process of structuring, and yet to something beyond this structure". ${ }^{65}$ So too does the framework of the furrows and the provision of water underpin the very existence of the process of structuring - the social structure of the town of Winterton formed around the physical "infra" of the furrows.

\section{REFERENCES}

Beinart, W., The Rise of Conservation in South Africa: Settlers, Livestock and the Environment, 1770-1950 (Oxford University Press, Oxford, 2003).

Bichsel, C., "Water and the (Infra)structure of Political Rule: A Synthesis", Water Alternatives, 9, 2(2016).

Christopher, A., "Natal, A Study in Colonial Land Settlement", PhD thesis, University of Natal, 1969.

Ertsen, M., “A Matter of Relationships: Actor Networks of Colonial Rule in the Gezira Irrigation System, Sudan", Water Alternatives, 9, 2(2016).

Etherington, N., Preachers, Peasants and Politics in Southeast Africa, 1835-1880 (Royal Historical Society, London, 1976).

63. Ertsen, “A Matter of Relationships", p 203.

64. McKenzie, "Social Sustainability”, p 23.

65. C. Bichsel, "Water and the (Infra)structure of Political Rule: A Synthesis", Water Alternatives, 9,2(2016), p 367. 
Lambert, J., Betrayed Trust: Africans and the State in Colonial Natal (University of Natal Press, Pietermaritzburg, 1995).

Lloyd's Publishing, Twentieth Century Impressions of Natal (Lloyds Greater Britain Publishing Co., London, 1906).

Marwick, C., "KwaMahlathi: The Story of Forestry in Zululand", Bulletin No. 49, Department of Forestry, Pretoria, 1973.

McKenzie, S., "Social Sustainability: Towards Some Definitions. Working Paper No. 27, McGill Hawke Research Institute, University of South Australia, 2004.

Middelmann, T.J.D., "The Hartebeestpoort Irrigation Scheme: A Project of Modernisation, Segregation and White Poverty Alleviation, 1912-1926", South African Historical Journal, 67, 2 (2015).

Tempelhoff, J., Time and the River: Observations on the Vaal River as Source of Water to the Witwatersrand, 1903-24, Historia, 46 (May 2001).

The (Natal) Land Board, The Winterton Irrigation Settlement, Natal (Times Printing and Publishing, Pietermaritzburg, 1905).

Thorrington-Smith, E., Towards a Plan for the Tugela Basin (Town and Regional Planning Commission, Pietermaritzburg, 1960).

Van Sittert, L., "The Supernatural State: Water Divining and the Cape Underground Water Rush, 1891-1910", Journal of Social History, (2004).

Visser, W., "Water as Agent for Social Change, 1900-1939: Two Case Studies of Developmental State Approaches in Establishing Irrigation Schemes", Historia, 63, 2 (November 2018).

Witt, H., "An Economic, Social and Environmental Study of Afforestation: A Case Study of Tree Growing in Natal, 1900-1960", MA dissertation, University of Natal, 1996. 